\title{
CHANGES IN THE HEART RATE AFTER PROCAINE
}

\author{
MICHIO TANIKAWA \\ Separiment of Pharmacoiogy, Hyush.u University Faculty of Medicine, Fukuoka \\ Received for publication November 10, 1953
}

In studying "the inhibitory action of procaine upon the reflex-bradycardia*," it was found to be necessary to make more detailed observation on the changes in the heart rate after procaine itself. Krause(1) reported recently that novocaine injected intravenously on dogs usually produced an increase of heart rate with a rise of blood pressure which continued from 2 to 15 minutes. The author's results on cats however did not fully agree with him. The heart rate was sometimes increased and at other times decreased. The mode of the change seemed to vary largely according to either the dose of procaine or the individual of the cat, and the present study was undertaken previously.

\section{METHODS}

Fourteen cats (from 2 to $4 \mathrm{~kg}$ in weight) anesthetized with $0.8-1 \mathrm{~g} / \mathrm{kg}$ of urethane were used, and a $10 \%$ solution of procaine hydrochloride was prepared. The necessary dose of the drug was diluted with $0.9 \% \mathrm{NaCl}$ solution to the amount of $1 \mathrm{cc}$ and injected slowly into the femoral vein in about $1-1 \quad 1 / 2$ minutes.

Effects on the blood pressure and the heart rate were measured at the tracing with a mercury manometer from the femoral artery. The respiration was also recorced with a tambour from the canulated trachea.

\section{RESULTS}

\section{1) Changes of the heart rate in course of time after procaine}

The heart rate of the cat showed various changes in about half an hour after injection as shown in Table 1. However, these cases can be classified into the following four types.

a) The heart rate increases immediately after procaine, thereafter turns into bradycardia about 5 minutes later and returns gradually to the normal in $20-30$ minutes.--See case No. $5,8,9,10,12,13(5 \mathrm{mg} / \mathrm{kg}) ; 1,6,8.9 .(10 \mathrm{mg} / \mathrm{kg}) ; 14(15 \mathrm{mg} / \mathrm{kg})$. 
b) The heart rate decreases mirute by minute after injection and begins to recover about $5-10$ mirutes later.- Sce No. $3,4(5 \mathrm{rg} / \mathrm{kg}) ; 2,3,11,12(10 \mathrm{mg} / \mathrm{kg}) ; 8,9$, $11(15 \mathrm{mg} / \mathrm{kg})$.

c) The heart rate shows a continuous increase during more than 30 minutes. -Sae No. $11(5 \mathrm{mg} / \mathrm{kg}) ; 7,10(10 \mathrm{mg} / \mathrm{kg})$ -

d) The heart rate decreases gradually after procaine and does not recover. - See No. $7(5 \mathrm{mg} / \mathrm{kg}) ; 4,13(10 \mathrm{mg} / \mathrm{kg}) ; 5(15 \mathrm{mg} / \mathrm{kg})$.

TABLE 1. Heart rate change after procaine (intact cats)

\begin{tabular}{|c|c|c|c|c|c|c|c|c|}
\hline $\begin{array}{l}\text { Dose } \\
\text { of } \\
\text { proc. }\end{array}$ & $\begin{array}{l}\text { Cise. } \\
\text { No. }\end{array}$ & $\begin{array}{c}\text { Before } \\
\text { proc } \\
\text { inj. }\end{array}$ & $\begin{array}{l}30 \text { sec. } \\
\text { after } \\
\text { proc. }\end{array}$ & $\begin{array}{c}1 \\
\min \end{array}$ & $\begin{array}{l}3-4 \\
\text { min. }\end{array}$ & $\begin{array}{l}5-6 \\
\text { Inir. }\end{array}$ & $\begin{array}{l}7-10 \\
\min .\end{array}$ & $\begin{array}{l}15-30 \\
\text { min. }\end{array}$ \\
\hline \multirow{11}{*}{$5 \mathrm{mg} / \mathrm{kg}$} & 3 & 150 & 138 & 132 & 130 & 130 & 138 & 144 \\
\hline & 4 & 150 & 150 & 145 & 141 & 130 & 120 & 130 \\
\hline & 5 & 160 & 160 & 160 & 170 & 165 & 150 & 153 \\
\hline & 7 & 160 & 150 & 150 & 140 & 140 & 140 & 140 \\
\hline & 8 & 180 & 190 & 186 & 180 & 170 & 160 & 155 \\
\hline & 9 & 124 & 138 & 138 & 120 & 120 & 120 & 122 \\
\hline & 10 & 126 & 142 & 140 & 130 & 123 & 126 & 126 \\
\hline & 11 & 168 & 168 & 168 & 168 & 170 & 174 & 180 \\
\hline & 12 & 156 & 156 & 156 & 126 & $126^{\circ}$ & 126 & 145 \\
\hline & 12 & 152 & 132 & 140 & 144 & 144 & 144 & 144 \\
\hline & 13 & 102 & 1.08 & 102 & 102 & 104 & - & - \\
\hline \multirow{13}{*}{$10 \mathrm{mg} / \mathrm{kg}$} & 1 & 150 & 170 & 180 & 150 & 135 & 130 & 120 \\
\hline & 1 & 114 & 126 & 132 & 132 & 130 & 126 & 126 \\
\hline & 2 & 110 & 105 & 105 & 105 & 105 & 105 & 110 \\
\hline & 3 & 174 & 135 & 125 & 120 & 120 & 120 & 145 \\
\hline & 4 & 204 & 185 & 180 & 170 & - & 150 & 150 \\
\hline & 6 & 159 & 198 & 186 & 153 & 147 & 150 & 150 \\
\hline & 7 & 135 & 140 & 150 & 145 & 145 & 150 & 160 \\
\hline & 8 & 147 & 160 & 156 & 150 & 146 & 138 & 140 \\
\hline & 9 & 122 & 138 & 138 & 120 & 120 & 126 & 130 \\
\hline & 10 & 129 & 120 & 124 & 129 & 132 & 138 & 147 \\
\hline & 11 & 180 & 159 & 162 & 162 & 168 & 170 & $18 \%$ \\
\hline & 12 & 192 & 168 & 150 & 125 & 120 & 120 & 144 \\
\hline & 13 & 123 & 123 & 120 & 120 & 120 & 120 & 102 \\
\hline \multirow{5}{*}{$15 \mathrm{mg} / \mathrm{kg}^{\prime}$} & 5 & 201 & 198 & 192 & 168 & 162 & 168 & 160 \\
\hline & 8 & 140 & 110 & 115 & 115 & 120 & 126 & 126 \\
\hline & 9 & 130 & 120 & - & 110 & 112 & 120 & 135 \\
\hline & 11 & 216 & 174 & 156 & 153 & 158 & 165 & 163 \\
\hline & 14 & 180 & 195 & 190 & 178 & 170 & 165 & 176 \\
\hline
\end{tabular}

Generally speaking, the heart rate tends to increase in smaller doses $(5-10 \mathrm{mg} /$ $\mathrm{kg}$ ) but tends to decrease in larger doses $(15 \mathrm{mg} / \mathrm{kg})$. It is remarkable that the change in the heart rate is always similar in the same individual. That is to 
say, repeated injection of $5-10 \mathrm{mg} / \mathrm{kg}$ of procaine into the same cat at enough long intervals (40-60 minutes) causes usually the same process of the change in the heart rate. But, the administration of procaine repeated more than three or four times usually lowers the blood pressure and decreases the heart rate.

\section{2) Influence of vagotomy on procaine actions}

The series of the above experiment were all performed in intact cats. Now, these cats are injected with $5-15 \mathrm{mg} / \mathrm{kg}$ of procaine after the both vagosympathetic trunks are sectioned at the neck, then the heart rate decreases in 12 out of 13 cases. In some of these cases the heart rate is increased by procaine before vagotomy but, after that, it is decreased even by the same dose of procaine as shown in Table 2. The cardiac acceleration by procaine can be observed so long as the heart is normally innervated by the vagus.

'I'ABLE 2. Heart rate change after procaine (vagocomized cats)

\begin{tabular}{|c|c|c|c|c|c|c|c|c|}
\hline $\begin{array}{l}\text { Dose } \\
\text { of } \\
\text { proc. }\end{array}$ & $\begin{array}{l}\text { Cise } \\
\mathrm{No} .\end{array}$ & $\begin{array}{c}\text { Before } \\
\text { proc. } \\
\text { inj. }\end{array}$ & $\begin{array}{l}30 \text { sec. } \\
\text { after } \\
\text { proc. }\end{array}$ & $\stackrel{1}{\min .}$ & $\begin{array}{l}3-4 \\
\text { min. }\end{array}$ & $\begin{array}{l}5-6 \\
\text { min. }\end{array}$ & $\begin{array}{l}7-10 \\
\text { min. }\end{array}$ & $\begin{array}{c}20-80 \\
\text { min. }\end{array}$ \\
\hline \multirow{5}{*}{$5 \mathrm{mg} / \mathrm{kg}$} & 5 & 135 & 135 & 130 & 120 & 120 & 120 & - \\
\hline & 7 & 145 & 140 & 140 & 138 & $14 ?$ & 144 & 144 \\
\hline & 8 & 135 & 138 & 138 & 138 & 138 & 139 & 132 \\
\hline & 11 & 180 & 168 & $\lceil 70$ & 170 & 170 & 170 & 170 \\
\hline & 12 & 169 & 156 & 156 & 156 & 156 & 156 & 156 \\
\hline \multirow{7}{*}{$10 \mathrm{mg} / \mathrm{kg}$} & 4 & 145 & 126 & 126 & 130 & 130 & - & - \\
\hline & 6 & 150 & 120 & - & - & - & - & - \\
\hline & 7 & 143 & 130 & 130 & 138 & 145 & 145 & $1 \leq 5$ \\
\hline & 8 & 132 & 105 & - & $0^{+}$ & & & \\
\hline & 10 & 141 & 114 & 114 & 120 & 100 & 81 & - \\
\hline & 11 & 172 & 150 & 145 & 150 & 150 & 156 & 164 \\
\hline & 12 & 156 & $96=$ & 144 & 144 & 148 & 150 & 152 \\
\hline $15 \mathrm{mg} / \mathrm{kg}$ & i1 & 153 & 135 & 120 & 120 & 135 & 144 & 150 \\
\hline
\end{tabular}

Note: + : the cat died due to cardiac standsill.

F: the cat in which marked arrhythmia was observed at ihis stage.

Case 8 only shows an increase of the heart rate after procaine.

\section{3) Parasympatholytic effect of procaine}

Shen and $\operatorname{Simon}(2), H e i m(3)$, Tanaka and Sakai(4) and others observed that intravenously injected procaine has a blocking effect on peripheral ends of the vagus. The author have also proved the same fact in the present experiment on 7 cats.

An efferent electrical stimulation of the vagosympathetic trunk sectioned at the neck is always followed by a marked bradycardia with a fall of the pressure, but this effect of ragal stimualtion is entirely abolished for a few minutes by the previous administration of procaine. The larger the dosage of procaine, the longer 
the period of the vagus blocking action. On the average this action persists for 3 to 4 minutes after $10-15 \mathrm{mg} / \mathrm{kg}$ of the drug but only for about a half minute after $5 \mathrm{mg} / \mathrm{kg}$.

Schneller(5), De Elio(6), Frommel, Favre and Valette(7), Riesser and Herrgott (8) and Krause(1) recognized the parasympatholytic effect of procaine (or novocaine) in various organs and tissues of various animals. In the present study on 5 cats the marked bradycardia caused by $0.001-0.02 \mathrm{mg} / \mathrm{kg}$ of acetylcholine injected intravenously was successfully inhibited by $5-10 \mathrm{mg} / \mathrm{kg}$ of procaine administered beforehand. And it is noticeable that the fall of the blood pressure synchronizing with the bradycardia was not depressed by procaine. Procaine blocks the cardiac cholinergic nerves but not the vasodilative cholinergic.

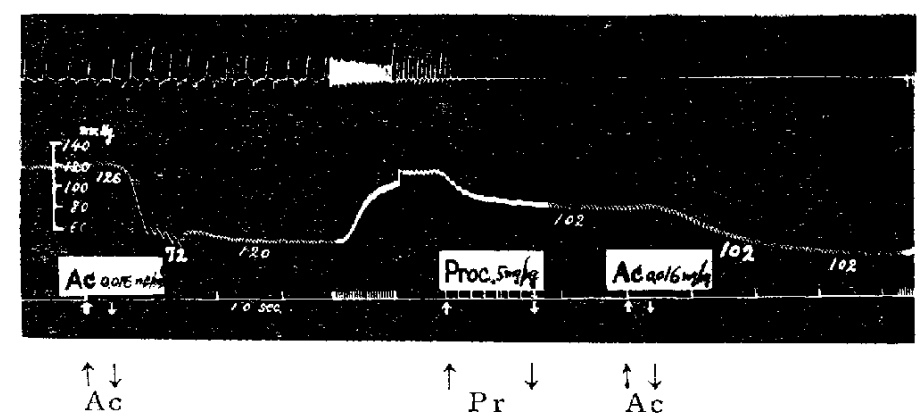

FIG. 1. Parasympatholytic effect of procaine upon the heart Cat $\frac{\text { o }}{;}, 2.6 \mathrm{~kg}$. At Ac $0.016 \mathrm{mg} / \mathrm{kg}$ of acetylcholine; at $\operatorname{Pr} 5 \mathrm{mg} / \mathrm{kg}$ of procaine, both intravenously. The bradycardia through acetylcholine disappears perfectly after procaine but the pressure fall can not be depressed. The number under the pressure tracing shows the heart rate.

\section{DISCUSSION}

There ariser a question why procaine makes the heart rate frequent or slow according to the iudividual.

Procaine has a fourfold action on the heart. First of all, it blocks the sensory nerve of the heart as supposed by Fleckenstein. In this laboratory, Kido(9) ascertained by an oscillograph that percamine (nupercaine) injected into pericardium was followed by a disappearance of afferent impulses from the heart of the cat, and Hirose (not yet reported) observed that $10 \mathrm{mg} / \mathrm{kg}$ of procaine injected intravenously into the cat abolished the afferent cardiac impulses caused by adrenaline or strophanthin. This paralytic effect on the sensory nerve depresses the cardiac reflex and acts acceleratively upon the heart rate in cooperation with the sinortic reflex inhibition. The inhibitory influence of vagotomy on the procaine tachycardia relates mainly on the exclusion of the cardiac reflex.

The second is the vagolytic, as described in this paper, which action blocks the impulses from the vagus center upon the heart and promotes the tachycardia. 
Thirdly, a sympathetic effect. Roth(10), Poulsson(11), Schaumann(12), Malorny and Orzechowski(13), MacGregor(14), and Chida(15) reported that procaine or cocaine in adequate dose stimulates sympathetic cardiac center and the pace maker in the heart, and causes cardiac acceleration.

But the last one acts in the opposite direction. Poulsson 11), Schaumann(12), MacGregor(14), Chida(15), Hazard(16), Brown and Acheson(17) observed the depressing effect of procaine, cocaine or other related local anesthetics upon the heart itself. This direct cardiac depression decelerates the heart rate and is believed to appear more markedly after relatively large dose of the drug.

It is obvious that these actions are not always equally aroused in every animal. In some cases accelerative action may be superior to decelerative, but the contrary can be seen in others. It depends on the physical condition or on the vagal and sympathetic tone and on the sensitivity of the heart to procaine etc. of the individual. The four types of the changes of the heart rate caused by procaine as indicated at the top of this article are thus induced from the different grade of each of the manifold action of procaine in different individual.

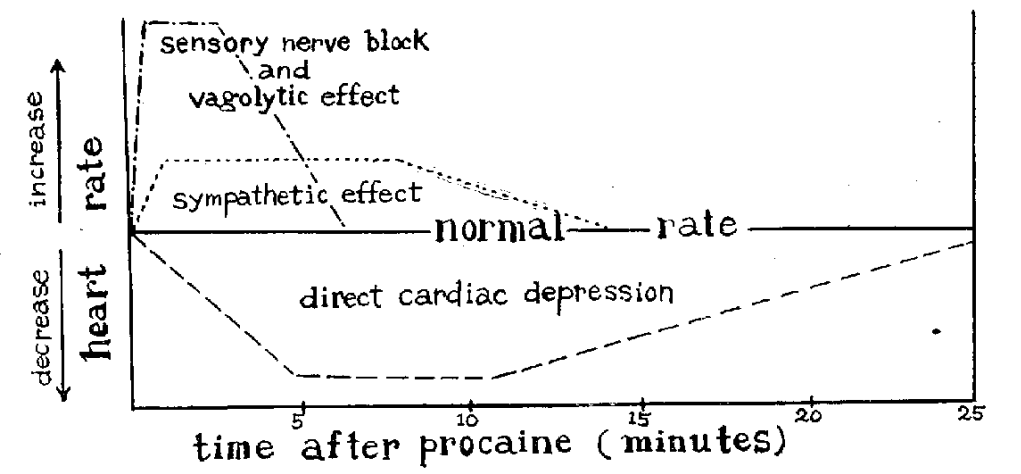

FIG, 2. Relation ketwe en the fourfold action of procaine upon the heart rate

\section{SUMMARY}

1. An intraverous injection of $5-10 \mathrm{mg} / \mathrm{kg}$ of procaine accelerates the heart rate in more than halí cases but decreases it in others. After $15 \mathrm{mg} / \mathrm{kg}$ of procaine the hoart rate decreases in almost all cases. The changes of the cardiac rate after procaine were arranged into four types.

2. When the vagosympathetic trunks have been sectioned, procaine produces almost always carcliac deceleration. The procaine tachycardia can be observed only in such a heart which is normally innervated by the vagosympathetic nerves.

3. Procaine is vagolytic. It blocks the efferent cardiac effects of vagal stimulation. This vagolytic action is also an important factor in the procaine tachycardia. The parasympatholytic effect of procaine is not seen in the blood vessels. 
4. The discussion was made about the fourfold action - three accelerative and one decelerative- of procaine upon the heart rate. Aforementioned four types of changes in the cardiac rate aiter procaine come from the fact that the accelerative and decelerative actions are not always equally aroused in each case.

\section{REFERENCES}

1) Krause, D.: Arch. exper. Path. u. Pharmabol. 213, 516 (1951)

2) SHeN, T.C.R. AND SIMON, M A.: Arh. internat. phamacjya. 59, 63 (1933)

3) Heim, F.: Areh. exper. Path. u. Phamahol. 212, 277 (1951)

4) TANAKA, K. AND SAKAI, S.: Jap.J. Fharmacol. 89, 43 (1952)

5) Schnelder, F.: Arch. enper. Pash. u. Pharmikol. 108, 73 (1985)

6) ELIo, F.[. DE: J. Pharmacol. \& Exper. Therap. 103, 3. (1948)

7) Frommet, E., FAVRE, M. ANi) VALerTe, I.: Arch. internat. pharmacodyn. 76, 341 (1943)

8) RIEsser, O. AND HeRRcotT, J.: Arch. exper. Poih. u. Pharmakol. 239, 95 (1950)

9) KIDO, R.: Hyushu Memoirs of Medical Sciences 3, 149 (1952)

10) Roth, G.B.: J. Pharmacol. \& Exper. Therap. 9, 352 (1917)

11) Poulsson, E.: Hdb. exper. Pharmakol. Bd, II, 1, 136 (1920)

12) SchaumanN, O.: Arch. exper. Path. u. Pharmabl. 10, 30 (1933)

13) MALORNY, G AND ORZECHOWSKI, G.: Ibid. 196, 260 (1940)

14) MACGregor, D.F.: J. Phamxcol. \& Expar. Thsrap. 66, 373 (1933)

15) CHIDA, C.: J.Jap. Rhino-Jtho-laryngol. 43, 399 (1942)

16) HAZARD, R.: Prog. Med. 73, 403 (1945)

17) BRown, B.B. AND ACHESON, G.H.: J. Pharmacol. \& Exper. Therap. 102, 200; 103,269 (1951) 